\title{
Tverrprofesjonell praksis, læring og samarbeid - forståelse av egen og andres rolle i læringsprosessen
}

\section{Nina Bøhle Cheetham}

Arbeidet med å implementere nye arenaer for tverrprofesjonell praksis er under stadig utvikling og gjenstand for omfattende forskning. I dette kapittelet diskuterer jeg tverrprofesjonell samarbeidslæring (TPS) i utdanning av helsefagstudenter. Ved hjelp av datamateriale fra to tverrprofesjonelle prosjekter, ett i en barneavdeling og ett i to distriktskommuner, utforskes medisin- og sykepleierstudenters rolle i og utbytte av samarbeidet.

\section{Innledning}

Spesialisthelsetjenesten er i endring og innleggelsestiden i norske sykehus blir kortere. Befolkningen blir eldre, og mange pasienter blir sendt hjem med komplekse og sammensatte helseutfordringer. Samhandlingsreformen og melding til Stortinget 13, (2012-2013) «Utdanning for velferd. Samspill i praksis» (Meld. St. 13 (2012-2013)) har aktualisert behovet for tverrprofesjonelt samarbeid. Helsepersonell har mindre tid til hver pasient på grunn av kortere liggetid. Kortere pasientforløp med større fokus på effektivitet vil kunne utfordre alle helseprofesjonene.

Pasientsikkerhet, yrkesetiske retningslinjer og den helhetlige omsorgen for hver enkelt pasient skal ivaretas. Dette krever innsikt i pasientens liv, historie og sykehistorie så vel som helsepersonells innsikt i og 
forståelse for hverandres roller, funksjon og arbeidsområder. Økt pasientsikkerhet og bedre kvalitet på helsetjenesten er et av målene. Tverrprofesjonell samarbeidslæring sees på som et av de store virkemidlene for å nå disse målene. Nye nasjonale retningslinjer for helse- og sosialfagutdanningene (RETHOS) har tatt konsekvensen av dette ved å utarbeide nye standarder og beskrivelser av sluttkompetanse for samtlige grunnutdanninger i helse- og sosialfag. Retningslinjene skisserer et krav om tverrprofesjonelt samarbeid i alle helsefaglige profesjonsutdanninger (Nasjonale retningslinjer for helse- og sosialfagutdanningene, 2020).

Tverrprofesjonell samarbeidslæring (TPS) har allerede fătt fotfeste i profesjonsutdanningene både nasjonalt og internasjonalt (CAIPE, 2017). Dette er blant annet begrunnet i WHOs engasjement og anbefalinger om betydningen av tverrprofesjonelt samarbeid mellom ulike helseprofesjoner (WHO, 2010). Læringsarenaene er blant annet felles praksis rundt pasienter, simulering, digitale læringsressurser og ulike typer av prosjektarbeid eller felles studieemner. Studier viser blant annet at tverrprofesjonelt samarbeid i løpet av utdanningen gir økt forståelse for hverandres arbeidsområder, og en opplevelse av å gi et bedre tilbud til pasienten (Clark, 2011; Kristensen, Flo \& Fagerstrøm, 2014; Kalvenes, Hjelle \& Tuven, 2016; Lidskog, Löfmark $\&$ Ahlström, 2008). Diskusjonen omfatter også tverrprofesjonelle studentpraksiser som arena for å oppnå trygghet på egen rolle og ansvar. Det argumenteres for at ved å legge til rette for tverrprofesjonelle læringsarenaer der studenter selv former sitt eget samarbeid, kan de ulike studentgruppene øve på, og lykkes i samarbeidet (Gudmundsen, Norbye, Dahlgren \& Obstfelder, 2018, 2019). Dette kan fremme trygghet på egen rolle og øke pasientsikkerheten. Men studier viser også at utdanningene har utfordringer med studentenes rolleforståelse, hierarki og tradisjonelle oppfatninger av profesjonene (Delunas \& Rouse, 2014; Renschler, Rhodes \& Cox, 2016). Ulike studier viser et mangfold av læringsaktiviteter knyttet til tverrprofesjonelt samarbeid rundt pasienten. Læringsaktivitetene introduseres i ulike faser av utdanningene og finner sted både på campus og i praksis. ${ }^{1}$ I kapittelet diskuteres resultater fra to tverrprofesjonelle prosjekter. Diskusjonen knyttes opp mot aktuell læringsteori.

Eksempler på TPS er TVERRSAM og TverrPrakt ved Norges teknisk-naturvitenskapelige universitet, NTNU, Fellesukene ved Høgskulen på Vestlandet og TVEPS ved Universitetet i Bergen / HVL / Bergen \& Fjell kommune, Førdemodellen og SAM-uken ved Stavanger universitetssykehus / Universitetet i Stavanger. 


\section{Profesjoner, roller og rolleforståelse}

En profesjon kan kjennetegnes ved at man er utdannet og sertifisert til å forvalte en bestemt type kunnskap (Molander \& Terum, 2008). Det forutsetter en utdannelse gjennomført etter vedtatte retningslinjer og med bestemte krav, gjerne med en kombinasjon av teori og praksis. En profesjon er videre basert på vitenskapelig kunnskap, altså at den er kunnskapsbasert. I begrepet profesjon ligger det at profesjonsutøveren skal tjene en annen parts interesser (Molander \& Terum, 2008). Profesjonsbegrepet har vært diskutert i flere tiår. Diskusjonen inkluderer teorier om makt og monopolisering av arbeidsoppgaver, noe som begrunnes i profesjonens ekspertkunnskap på det aktuelle området. En nyere forståelse av profesjoner er at profesjonene selv har makt til å definere kvaliteten på det profesjonelle arbeidet. Begrepet skjønn bringes også inn (Molander \& Terum, 2008, s. 179).

En persons profesjonelle identitet formes gjennom hans eller hennes erfaringer i rollen som profesjonsutøver, men også gjennom å bli speilet av andre. En rolle defineres gjerne som et sett av forventninger og normer som rettes mot en person i en bestemt sosial posisjon. Denne rollen foregår alltid i en relasjon til en annen, i en eller annen sammenheng (Ingstad, 2013). Den preges gjerne av hvordan personen blir møtt, og hvilke forventninger andre har til vedkommende. Dette er med på å forme personens oppfatning av seg selv i rollen. Til slutt blir rollen en del av hans eller hennes virkelighetsforståelse. Rollekonflikter kan oppstå i de tilfellene der forventningene til vedkommende ikke samsvarer med andres forventninger. Et annet element som kan påvirke rollen, er den enkeltes personlige identitet knyttet til, i dette tilfellet, den enkeltes profesjon. Rollen formes blant annet gjennom utdanning, forventninger fra samfunnet og fra den enkelte selv (Ingstad, 2013).

På den annen side kan rolleforventningen fra andre og oppfattelse av egen rolle utfordres ved at nye elementer og endringer $i$ ansvar og arbeidsoppgaver kommer inn. Et eksempel kan være diskusjoner rundt spesialistutdanning for sykepleiere i den hensikt å gi dem kunnskap og myndighet til å utføre oppgaver som tradisjonelt er utført av leger.

Et annet eksempel er når helsefagarbeidere får delegert medisinansvar, noe som tradisjonelt har vært en oppgave forbeholdt sykepleiere.

Tverrprofesjonelt samarbeid er ikke det samme som å sitte sammen og jobbe. Poenget med tverrprofesjonell samarbeidslæring er at studentene skal lære å samarbeide i tverrprofesjonelle team rundt pasienten for å gi denne best 
mulig helsehjelp. Hensikten med å introdusere TPS i utdanningen er nettopp å møte denne utfordringen for å sikre kvalitet og en bedre pasientopplevelse. Den bygger på WHOs definisjon av tverrprofesjonell utdanning:

«Interprofesjonell utdanning finner sted når to eller flere profesjoner lærer om, fra og med hverandre for å oppnå effektivt samarbeid og forbedre helseresultater» (WHO, 2010, s. 7). ${ }^{2}$

Studentene må lære samarbeid, ikke bare lære sammen. Definisjonen bruker formuleringen «lærer om og fra» noen, noe som kan utgjøre et viktig fundament for forståelsen av de ulike profesjonene, og hvilken rolle de har i samarbeidet.

\section{Materiale og metode}

Studien er basert på intervjuer av studenter som deltok i to ulike prosjekt: «Tverrprofesjonell samarbeidslæring i helsefaglig praksis» (Norbye, 2016) og «Tverrprofesjonelt samarbeid mellom medisinstudenter og sykepleierstudenter i praksis i spesialisthelsetjenesten» (Cheetham, 2016). Studiene ble meldt til Norsk senter for forskningsdata (NSD) og informasjonsbrev og intervjuguide for begge prosjektene ble godkjent (NSD, prosjektnummer 34895 og 51500).

\section{Tverrprofesjonell samarbeidslæring i helsefaglig praksis}

Prosjektet utforsket et praksissamarbeid mellom bachelorstudenter i sykepleie, ergoterapi og fysioterapi i tredje og siste studieår samt medisinstudiet i femte studieår. Målet var å utforske studentenes læring i arbeid med reelle pasienter i tverrfaglige team i kommunehelsetjenesten (Norbye, 2016). Studenter fra de ulike profesjonene var organisert i til sammen ni team som samarbeidet $\mathrm{i}$ en to ukers praksis i to distriktskommuner. Teamene fikk ansvaret for to til tre pasienter, hver med komplekse og sammensatte helseutfordringer. Hvert team hadde en gruppeveileder i tillegg til at studentene hadde en profesjonsspesifikk kontaktperson. Studentene planla selv hvordan de skulle samarbeide rundt kartlegging av pasientens behov for helsehjelp,

Interprofessional education occurs when students from two or more professions learn about, from and with each other to enable effective collaboration and improve health outcomes. 
behandling og pleie. Tiltak ble, basert på møter med pasienten, bestemt på daglige samarbeidsmøter. Etter sin to ukers praksis presenterte gruppen sine resultater samt forslag for videre behandling og pleie for de aktuelle pasientene. Studentene ble rekruttert gjennom informasjonsfoldere og møter, og all deltakelse var frivillig. Deltakerne kunne når som helst trekke seg fra prosjektet. Min forskning i dette prosjektet utforsker kun samarbeidet mellom medisinstudenter og sykepleierstudenter.

\section{Tverrprofesjonelt samarbeid i praksis i spesialisthelsetjenesten}

Prosjektet utforsket et samarbeid mellom medisinstudenter og bachelorstudenter i sykepleie i praksis i spesialisthelsetjenesten. Det inkluderte medisinstudenter i siste studieår og sykepleierstudenter i andre studieår med praksis i en barneavdeling. En medisinstudent og en sykepleierstudent samarbeidet om mottak av pasient som kom for innskriving i avdelingen (Cheetham, 2016). Studentene og en studentansvarlig sykepleier møttes for planlegging før mottaket. Etter at pasientmottaket var gjennomført, møttes de igjen til en felles oppsummering. Medisinstudentene gjennomførte anamnese og klinisk undersøkelse. Sykepleierstudentene supplerte med sykepleieanamnese. Sammen vurderte studentene hvilke oppgaver som skulle følges opp, og av hvem. Sykepleierstudentene gjennomførte aktuelle sykepleieoppgaver som for eksempel måling av høyde, vekt og temperatur, urinprøvetaking, forberedelser til blodprøver og kartlegging av barnets vaner knyttet til søvn, lek og kosthold. Studentene ble orientert gjennom informasjonsskriv og møter før praksisstart. Deltakelse var frivillig og hadde ikke betydning for om praksis ble godkjent eller ikke. Deltakelse i det tverrprofesjonelle samarbeidet innebar ikke at studentene forpliktet seg til å delta i studien, men de ble informert om at de kom til å bli forespurt.

\section{Datainnsamling og analyse av data}

Semistrukturerte individuelle intervjuer og gruppeintervjuer av til sammen sju medisinstudenter og åtte sykepleierstudenter danner grunnlag for datamaterialet. Av disse var tre medisinstudenter og tre sykepleierstudenter fra 
prosjektet i sykehus. Fem sykepleierstudenter og tre medisinstudenter fra prosjektet i kommunehelsetjenesten er intervjuet. Intervjuene ble gjennomført av tre ulike personer med tilknytning til de to prosjektene. Det ble benyttet intervjuguide i begge prosjektene. Intervjuguide til prosjektet i barneavdelingen var utarbeidet av forfatter. Intervjuguide til prosjektet i kommunen ble utviklet i fellesskap av prosjektgruppen som planla og gjennomførte prosjektet. Intervjuene ble anonymisert og ordrett transkribert. De transkriberte intervjuene ble analysert ved hjelp av meningsfortetting som beskrevet av Kvale og Brinkmann (Giorgi, Fischer \& Murray (1975) i Kvale, Brinkmann, Anderssen \& Rygge, 2015, s. 213). Intervjuene ble lest gjentatte ganger uten fortolkning, beskrevet som naiv lesning. Utsagn som var felles for flere intervjuer ble notert og gruppert. Notatene dannet grunnlaget for identifisering av tema knyttet til læring i en TPS-praksis.

\section{Pålitelighet og overførbarhet}

Kvale (2015, s. 218) tematiserer kritikk av meningsfortolking som vitenskapelig metode. Kritikken peker på at ulike personer vil finne ulike meninger i samme intervju. Det er ikke sikkert at informantens egentlige mening kommer frem i tolkningen. Spørsmålene som blir stilt, vil være preget av intervjuerens forforståelse. Min erfaring fra praksis om verdien av et godt tverrprofesjonelt samarbeid mellom lege og sykepleier, kan påvirke gjennomføringen av intervjuene. På samme måte vil min rolle som ansvarlig for et av studentprosjektene samt min forforståelse og erfaring knyttet til tverrprofesjonell praksis, kunne ha betydning for hvordan jeg tolker studentenes fortellinger. Studentene som blir intervjuet, representerer et utvalg og er ikke nødvendigvis representative for alle studenter. Konteksten for studentene er ulik og kan påvirke hvordan de opplevde egen rolle, samarbeid og læringsutbytte. Temaene har likevel verdi da studentene i begge kontekstene arbeidet med å lære av, med og om hverandre i sin grunnutdanning. 


\section{Resultater}

Sentrale tema som fremstod etter analysen av intervjuer fra begge prosjektene, var:

- Om roller og rolleforventning

- Om å lære

- Samarbeid

\section{Om roller og rolleforventning}

Profesjoner og rolleforståelse er tematisert tidligere i dette kapittelet og er også diskutert i siste del av kapittelet. Hvilken rolle den enkelte har i en gruppe, kan endre seg ved endret gruppesammensetning og har ofte sammenheng med status (Sylte, 2018, s. 191). I denne studien vil roller også kunne være knyttet til det fagspesifikke.

Begge studentgruppene tematiserte egne og andres roller i samarbeidet. En av medisinstudentene fra prosjektet i kommunen forteller at veilederen foreslo at han, studenten, skulle ha rollen som den samlende og ansvarlige, sammenfatte bidragene fra de andre profesjonene og formidle dette i møtet om pasienten. Selv om alle profesjonene i dette prosjektet var til stede på møtet, ble medisinstudenten tildelt en rolle som «ordfører», og veilederen forventet at han skulle si noe om veien videre i behandlingsforløpet.

«... han (veileder) snakka om det at du er jo lederen, du skulle være den medisinsk faglige lederen for gruppa». Studenten fortalte at sykepleierstudenten gjorde gode observasjoner og rapporterte viktige funn, og han fremholdt at hun hadde fortjent en større og tydeligere rolle i gruppen.

En annen av de fire medisinstudentene i samme prosjekt har en annen beskrivelse. Hun opplevde at pasientene hadde ulike forventninger til de ulike profesjonene og beskrev hvordan de klarte å løse dette ved å innta ulike roller inne hos pasienten. De gjorde blant annet egne observasjoner ved å gjøre ulike aktiviteter med pasienten.

Studentene fra begge profesjonene i barneavdelingen diskuterte på forhånd hvordan de, i pasientmottaket, skulle fordele spørsmålene de stilte. En av de tre medisinstudentene mente at det var naturlig at sykepleieren stilte spørsmål om skole og fritidsaktiviteter, og at det kunne ha noe med tiltenkte roller å gjøre. 
Sykepleiere fra prosjektet i kommunen tematiserte den sammensatte rollen de hadde som sykepleiere. De opplevde det som vanskelig å forklare hva sykepleie var i det tverrfaglige samarbeidet. Sykepleie kunne romme mange ulike elementer, alt fra stell, medisiner og prosedyrer til samtaler, turer og trening. De syntes sykepleie integrerte fagområder som medisin, fysioterapi og ergoterapi «... man har jo flere roller enn bare sykepleier. Det er gjerne at du nesten er en fysioterapeut, du er nesten en ergoterapeut, du skal liksom gjøre alle observasjonene.»

\section{Om å lære}

Tverrprofesjonell samarbeidslæring bygger i stor grad på en sosiokulturell læringsteori. Perspektivet i denne teorien er at læring skjer i samhandling og samspill med andre (Sylte, 2018). Dette læringssynet kan praktiseres ved at studenter samarbeider i grupper rundt pasienten slik som i prosjektet i kommunen. Gruppen blir dermed en viktig ressurs. Også samhandling mellom sykepleierstudent og medisinstudent i barneavdelingen skjer i et sosiokulturelt perspektiv ved at studentene samhandler og reflekterer i fellesskap i etterkant av læringsaktiviteten. Praksisfeltet kan på den måten bli en god arena for læring, der dialog er en viktig forutsetning for best mulig utbytte.

I intervjuene fra prosjektet i kommunen kom det frem at studentene økte sin forståelse av hverandres arbeidsoppgaver gjennom diskusjonene knyttet til hver enkelt pasient. De delte sine observasjoner og kunne på den måten bedre forstå hvordan de var kommet frem til samme resultat, men på ulike måter. Synspunktene studentene delte, gjorde også at de ble mer oppmerksomme på hverandres funksjon.

For medisinstudentene i begge prosjektene kunne dette imidlertid komme i konflikt med det å få gjennomført arbeidskravene knyttet til utdanningen. En av studentene uttrykte det slik: «Det var to uker av vår praksis. Jeg ville lære noe, ikke bare den tverrfaglige biten. Jeg ville faktisk ha noe faglig ut av det.»

En annen av medisinstudentene fra prosjektet i kommunen beskrev hvordan hun lærte av de andre profesjonene gjennom å jobbe sammen rundt en pasient som hadde problemer med personlig hygiene og påkledning. Hun avsluttet likevel med en innvending om at hun ikke syntes hun fikk så mye medisinskfaglig ut av samarbeidet med de andre. Diskusjonene i gruppen 
åpnet opp for viktige refleksjoner hos en av medisinstudentene. Han reflekterte rundt at det finnes et menneske bak ethvert prøvesvar, ikke bare «grønne eller røde svar» på et dokument.

En sykepleierstudent i barneavdelingen fortalte om sin opplevelse av pasientmottak: «Første gangen følte jeg meg litt som barnepike for barnet mens mor snakket med lege.» Senere i praksisen oppdaget hun at denne typen samvær var viktig for videre observasjon og pleie av barnet. En av medisinstudentene i barneavdelingen beskrev hvordan han i det første av to mottak var mest opptatt av å følge listen over momenter som skulle gjennomgås, noe som resulterte $\mathrm{i}$ at han ikke fulgte så nøye med på sykepleierstudentens handlinger. Dette endret seg i det andre mottaket han deltok i.

\section{Samarbeid}

Samarbeid handler om å jobbe sammen, å arbeide i fellesskap for å nå et felles mål. WHO utdyper: «Samarbeidende praksis i helsearbeid skjer når flere helsearbeidere fra ulike profesjoner sørger for omfattende tjenester gjennom å arbeide med pasienter, deres familier, omsorgspersoner og samfunn for å tilby helsetjenester av best mulig kvalitet i ulike situasjoner» (min oversettelse) (WHO, 2010, s. 173).

Studentene fra prosjektet i kommunen beskrev et godt samarbeid i gruppa. De var heller ikke redde for å avdekke egen manglende kunnskap i diskusjonene rundt pasienten. En av medisinstudentene deltok i mange av sykepleierens oppgaver. Både hun og sykepleieren i gruppen beskrev hyppige diskusjoner og mye samvær.

En av sykepleierstudentene i barneavdelingen problematiserte at hun opplevde å måtte vente på og tilrettelegge før medisinstudenten var klar for pasientmottaket. Dette skyldtes at medisinstudenten hadde dårlig tid mellom egne oppgaver. Hun fulgte med på når den andre var klar, og ville gjerne legge til rette for en best mulig situasjon rundt pasientmottaket. Medisinstudenten på sin side måtte fordele tiden mellom seminar og praksis. Enkelte ganger uteble medisinstudentene fra avtalt møte fordi de allerede hadde gjennomført sine to obligatoriske mottak. Avtalene mellom studentene kunne være uklare.

\footnotetext{
Collaborative practice in health-care occurs when multiple health workers from different professional backgrounds provide comprehensive services by working with patients, their families, carers and communities to deliver the highest quality of care across settings.
} 
En av sykepleierstudentene reflekterte over at medisinstudenten hadde det travelt, men opplevde likevel samarbeidet som positivt og relevant. Hun beskriver et godt forberedt pasientmottak: «Jeg følte at sykepleieoppgavene og legeoppgavene gled veldig inn i hverandre ved mottak. Det var veldig positivt at begge to var der. Vi kunne svare på ulike typer spørsmål, det legen ikke kunne svare på kunne jeg svare på.» Hun savnet medisinstudenten når hun hadde mottak alene, og følte at hun manglet en del informasjon om pasienten som ville vært relevant, men som det ikke var naturlig for henne å innhente.

Studenten fortalte at det var hun som foreslo rekkefølgen på gjøremål i mottaket på bakgrunn av sykepleiefaglige vurderinger rundt det å skape tillit hos pasienten. Hun argumenterte for dette ved å peke på behovet for å gjøre undersøkelsene så lite skremmende som mulig. Hun brukte sin sykepleiefaglige kunnskap i argumentasjonen og fikk gehør hos medisinstudenten. Medisinstudenten stolte på sykepleieren og på at hun var kjent $\mathrm{i}$ avdelingen. I det oppsummerende møtet etter pasientmottaket uttalte sykepleierstudenten: «... alt ligger egentlig i forberedelsen», og medisinstudenten var enig: «Det er bedre når man vet hva den andre gjør.»

En av medisinstudentene fortalte at hun var mest opptatt av det hun selv skulle gjennomføre, og at de nesten aldri samarbeidet med sykepleierstudenter i løpet av studietiden. Studenten fremholdt at et samarbeid burde gå som en rød tråd gjennom studieforløpet. Da ville det forplantet seg ut i jobblivet og skapt bedre forståelse for oppgavene knyttet til de ulike profesjonene, «... både respekt og kommunikasjon, veldig mye kunne blitt bedre tror jeg».

\section{Diskusjon}

I diskusjonen refererer jeg til forskning knyttet til tverrprofesjonell praksis og relevant læringsteori. Til slutt diskuterer jeg implikasjoner for utdanningsinstitusjonene og hvordan erfaringene kan brukes til videre utvikling av den tverrprofesjonelle læringen til studentene.

På bakgrunn av resultatene diskuteres følgende:

- Oppfatning av egen og andres rolle.

- Studentenes opplevelse av eget læringsutbytte av samarbeidet.

- Betydningen av grunnleggende kunnskap om den andres profesjon for forståelsen for hverandres fag. 


\section{Blir rollene utfordret i tverrprofesjonelt samarbeid?}

Flere studier trekker frem medisinstudenters oppfatning av å ha en slags lederposisjon i pasientarbeidet. De ser på seg selv som ansvarlige for hele pasientforløpet og at de har et spesielt ansvar for den totale pasientbehandlingen (Aase, Aase \& Dieckmann, 2013; Aase, Hansen \& Aase, 2014; Friman, Wiegleb Edström \& Edelbring, 2017). Det kan synes som at det er vanskelig for medisinstudenter å se sykepleiefaget som et eget fag, i motsetning til medisin (Rose, Smith, Veloski, Lyons, Umland \& Arenson, 2009). Det samsvarer med uttalelser fra enkelte deltakere i våre studier. Det er mulig at en oppfatning av at legen er ansvarlig for «alt», kan bli etablert gjennom studieforløpet. Kanskje det samsvarer med det samfunnet tradisjonelt forventer av en lege? Sykepleiere kan også tenkes å være formidlere av denne rolleoppfatningen. Men medisinstudenten er ikke ansvarlig for det sykepleiefaglige, og det bør være tydelig både for lege og sykepleier. Det er derfor viktig at sykepleierstudenten står frem som en trygg formidler av eget fag. Selv om studentene starter studiet med en bestemt oppfatning av yrket og hva det innebærer, formes studentenes profesjonelle identitet gjennom hele studieforløpet. Roller formes også gjennom gruppeidentitet, de har noe til felles som skiller dem fra andre (Ingstad, 2013). Dette gjelder selvsagt for alle studentgrupper.

Eksempler fra de to prosjektene i studien viser at det kan være vanskelig for sykepleierstudentene å beskrive egen funksjon. En av studentene uttalte at hennes funksjon var «stor og omfavnet alt». Hun oppfatter at sykepleie inkluderer både fysioterapi og ergoterapi, og viser til sykepleien som en del av de andres funksjon og ikke bare avgrenset i seg selv. Det kan bety at hun ser det de har felles. Samtidig som at hun ser pasientens behov og sin egen rolle tydelig, blir den også utydelig fordi den innehar elementer av andres roller. Denne studenten møter for første gang sin egen rolle i møte med de andre. Hun er i en utvikling i å forstå hva som er hver enkelt profesjons rolle eller funksjon.

Banduras sosiale læringsteori fremholder at profesjonelle stereotypier formes gjennom innflytelse fra læringsmiljøet, gjennom observasjon og imitasjon. Man er deltaker i et yrkesfellesskap (Bandura \& Walters, 1977; Sylte, 2018; Lockeman, Appelbaum, Dow, Orr, Huff, Hogan \& Queen, 2017). Resultater fra en norsk studie viser at tradisjonelle mønster og rolleoppfatninger fortsatt har stor innflytelse på studentenes fordeling av ansvar på tvers av 
sykepleie- og medisinfaget. Videre viser studien at gruppekultur var bestemmende for teamarbeidet (Aase et al., 2014). I et tverrprofesjonelt samarbeid rundt simulering utviklet studentene imidlertid en mer positiv innstilling til hverandre (Lockeman et al., 2017). Artikkelforfatterne foreslår i større grad å fokusere på roller og identiteter i tverrprofesjonelle prosjekter. Det kan være viktig å bevisstgjøre studentene på egen rolle og identitet når TPS introduseres i undervisningen.

Medisinstudenter oppfatter gjerne sykepleiere som organisatorer som har oversikt over pasientforløpet, men også som holistisk orienterte som i større grad tar pasientperspektivet i samarbeidet. Frimann et al. (2017) finner at medisinstudentene selv mener at de har stor kunnskap om sykepleierens arbeidsområder. Sykepleierne mener det motsatte (Friman et al., 2017). Selv om flere studier avdekker at medisinstudentene får større forståelse for sykepleierens arbeidsområder gjennom TPS, er det også studier som viser stereotypier (Rose et al., 2008; Delunas \& Rouse, 2014; Renschler, Rhodes \& Cox, 2016). Sykepleiere på sin side beskriver ofte en større forståelse for legens arbeidsområder etter TPS, og deres noe stereotypiske oppfatninger av leger ser ut til å endres (Friman et al., 2017; Lockeman et al., 2017).

En utfordring i TPS kan være at medlemmer av en enkelt profesjon ser på seg selv som den opplagte leder av et gruppesamarbeid. Å være den medisinsk ansvarlige innebærer ikke nødvendigvis ledelse av samarbeidet i gruppen. I tillegg til å kunne oppleves som udemokratisk, kan det hindre viktige innspill fra de andre deltakerne. Det er heller ikke sikkert at man er egnet til å lede bare fordi man har en bestemt profesjon. Hvis samarbeidet faktisk forutsetter en leder, kan man, ved å åpent diskutere lederskapet i gruppen og kartlegge både interesse og egnethet, øke sjansen for å få den lederen gruppen er best tjent med.

Rolleoppfatning synes å kunne påvirke studentenes samarbeid. I et av eksemplene fra praksisen i kommunen uttaler medisinstudenten at det ikke var noen som hadde behov for å være sjef eller markere seg i en lederrolle. Sykepleierstudenten i samme gruppe forteller at alle var sammen om stell av pasient, og at studentene hadde et uttalt samarbeid. Det kan synes som at denne studentgruppen etablerte et annet gruppesamarbeid enn den andre gruppen i samme prosjekt. 


\section{Studentene utfyller hverandre gjennom samarbeid}

Studentene formes gjennom praksis, undervisning og ulike rollemodeller som de møter i løpet av studietiden. Medisin og sykepleie er to ulike fagområder med flere fellestrekk og gjensidig avhengighet. Dersom lærere og praksisveiledere i sykepleierstudiet selv har problemer med å beskrive sykepleierrollen og ikke oppfatter seg selv som ledere av eget fag, kan det påvirke studentens evne til å etablere en selvstendig rolle som sykepleier. Det å kunne beskrive eget fag er viktig for å kunne fremstå som trygg i rollen som yrkesutøver $\mathrm{i}$ et tverrprofesjonelt samarbeid. Viktigheten av å investere i egen identitet i samarbeidet diskuteres senere (Lave \& Wenger, 2003). Alle helseprofesjoner er viktige i dette samarbeidet. Et godt samarbeid avhenger også av god kommunikasjon mellom profesjonene. Å anerkjenne hverandres ulikheter og betydningen av hverandres kunnskap kan ha betydning både for samarbeidet og utfall av pasientbehandling. En studie fra et amerikansk universitet viser at studentene utviklet en mer positiv innstilling til hverandre etter samarbeid knyttet til pasientarbeid (Wong et al., 2016).

Studenter fra både sykepleie og medisin fremhever at tid til refleksjon over samarbeidet, det å sitte sammen og snakke, hadde betydning for utbyttet. De fikk en innsikt i den andres fagområde som de ikke hadde fra før. Et par av studentene bemerket at denne tiden manglet $i$ «det virkelige liv». Mangel på samarbeidserfaring fra studiet ble tematisert av flere av studentene. Studenter i barneavdelingen hadde et dårligere utbytte av samarbeidet hvis de var dårlig forberedt og ikke hadde planlagt mottaket sammen.

En forsker fra prosjektet i kommunen peker på at det å la studentene selv forme sitt samarbeid økte studentenes evne til å samarbeide rundt pasienten (Gudmundsen et al., 2019). En annen norsk studie, «Førdemodellen», utforsket et tverrprofesjonelt samarbeid mellom sykepleier- og medisinstudenter, der studentene sammen skulle ta ansvar for forløpet til pasienten. I denne modellen planla studentene selv utredning, pleie og behandling med veiledning av ansvarlig sykepleier og lege. Studien viser at studentene ikke opplevde ulikt maktforhold i teamene, de var trygge på hverandre og opplevde trygghet på oppgavene til den andre profesjonen (Andersen, Baerheim \& Hovland, 2017). I TPS etter «Førdemodellen» fortalte studentene at det ble lettere å ta kontakt på tvers av profesjoner etter samarbeidet, og de fikk økt forståelse for den andres betydning i pasientarbeidet. Studentene i barneavdelingen kunne 
vært bedre forberedt på eget bidrag til læring. Et definert mål om et felles ansvar for forløpet til pasienten kunne bidratt til å flytte fokus fra egen rolle og funksjon over på samarbeid.

\section{Læringsutbytte gjennom TPS}

Studentene i begge prosjektene uttrykker økt læring og stort utbytte av det tverrfaglige samarbeidet. Læringen skjer, slik jeg ser det, med visse forbehold fordi det er ulike faktorer som ligger til grunn for om man oppnår målet med TPS: å lære av og med hverandre i et samarbeid rundt pasienten. Studentene har også ulike forventninger til hva de skal lære.

Medisinstudentenes oppfatning av læringsutbytte i de to prosjektene som er presentert her, varierer. Flere ser nytten av samarbeidet. Samtidig uttrykker to av medisinstudentene et ønske om at det «faglige» utbyttet kunne vært bedre. Medisinstudenter fra begge prosjektene var opptatt av «å få gjort mest mulig». Det er stort press på å få gjennomført studiets arbeidskrav og å utnytte praksisen slik at man får «krysset av» for alle oppgavene man skal ha trent på. Dette ser ut til å ha fokus i begge prosjektene og kan synes viktigere enn å få deltatt $\mathrm{i}$ et tverrprofesjonelt fellesskap. En av medisinstudentene i våre studier oppsøkte egne arenaer for læring. Enkelte studier viser at det, sammenlignet med de andre helseprofesjonene, er medisinstudenter som minst verdsetter TPS som en relevant læringsarena (Delunas \& Rouse, 2014; Renschler et al., 2016). Men en studie fra 2014 viser det motsatte, nemlig at medisinstudentene var de som verdsatte det tverrprofesjonelle samarbeidet høyest (Park, Hawkins, Hamlin, Hawkins \& Bamdas, 2014). TPS i denne studien besto av korte forelesninger, diskusjoner, rollespill og arbeid med case. Studien inkluderte sykepleierstudenter, medisinstudenter og sosialarbeiderstudenter. Også i våre studier er oppfatningene delte.

Det er viktig å synliggjøre at læring i et tverrprofesjonelt fellesskap kan inneholde et annet fokus og læringsaspekt enn det studenten tradisjonelt forbinder med læring. Læringen innbefatter ikke nødvendigvis bare det studenten oppfatter som «faglig». Sosiokulturell læringsteori fremholder at læring ikke foregår i et vakuum, men i en sosial kontekst. Den foregår i interaksjon mellom mennesker og aktiviteter (Säljö \& Moen, 2001). Studentene har ofte lite tverrprofesjonell erfaring gjennom studier og fra arbeidsliv. Det forteller også våre informanter. Det kan derfor være vanskelig for studenter å se nytten 
av denne læringsformen i et lengre perspektiv. En individualistisk tankegang kan også være til hinder.

Studenter kan oppleve en konflikt mellom de tradisjonelle læringsutbyttene i studiet og nye læringsutbyttebeskrivelser. Det kan være utfordrende å bli presset over i nye samarbeidsformer og praksisfellesskap. Helsefaglige utdanningsinstitusjoner trenger å formidle for alle studentgrupper at den typen læring som utvikles $\mathrm{i}$ et fellesskap med andre profesjoner, kan være med på å gi dem kunnskap og erfaring som kan komme til nytte når de senere skal praktisere i sine profesjoner. Det til tross for at dette er en annen type kunnskap enn den som til enhver tid formidles som viktig og nødvendig gjennom læreplaner og eksamenskrav. Deltakelse i TPS gir dem mulighet til å øve ved å sette sammen kunnskap og ferdigheter i samarbeid med andre yrkesgrupper. Man kan kalle det en form for «sosiale aktiviteter». Ulike individer har ulik kompetanse, derfor må også læringen være sosial (Säljö \& Moen, 2001). Et praksisfellesskap er nettopp en sosial arena der læring er det som driver praksis. I praksisfellesskapet investeres det i gjensidige relasjoner som er meningsfulle i samhandling med hverandre (Lave \& Wenger, 2003).

Videre kan TPS fremskynde en læring som ellers kommer med modenhet og yrkeserfaring. Wenger (2003) fremholder at læringen er det som driver praksis, og at praksisfellesskaper både er påvirkelige og motstandsdyktige. Hun poengterer viktigheten av å investere egen identitet i et praksisfellesskap og fremholder at evnen til tilpasning kjennetegnes av nettopp påvirkelighet og motstandskraft. «Læring innebærer et tæt samspill mellom orden og kaos» (Lave \& Wenger, 2003, s. 171). For å være «motstandsdyktig» i et praksisfellesskap trenger man en trygghet på eget fag og rolle slik sykepleierstudenten i samspill med medisinstudenten i pasientmottak i barneavdelingen formidler: «Det var veldig positivt at begge to var der. Vi kunne svare på ulike typer spørsmål, det legen ikke kunne svare på kunne jeg svare på.»

\section{Implikasjoner for helseprofesjonsutdanningene}

Nye nasjonale retningslinjer for helsefaglige utdanninger (RETHOS) krever fokus på TPS. Studentene former etter hvert en identitet i egen helseprofesjon, og man må kanskje finne den for å gi andre plass. Nytteverdien oppdages kanskje senere, men TPS i utdanningen kan gi en slags beredskap for 
hva som møter dem etter endt studium. En tverrprofesjonell praksis er en arbeidsmåte som gjennom forberedelse og erfaring senere kan oppleves som en «nødvendig» måte å arbeide på. Kanskje er det slik at først i en tverrprofesjonell praksis, vil egen styrke bli tydelig.

Læring krever tålmodighet og forberedelse. Et spørsmål som bør stilles, er hvordan studentene best kan forberedes til det tverrprofesjonelle møtet eller praksisen, og hvordan påvirkes forventningene de har til programmet de skal være med på? For å forberede studentene gjennom studieforløpet må TPS integreres i utdanningene i større grad enn i dag. En konsekvens av det kan være at utdanningsprogrammene må gi slipp på noen av sine egne krav for å gi rom til en bedre forberedelse til TPS. I Toronto-modellen for TPS (Nelson, Tassone \& Hodges, 2014) beskrives ulike pedagogiske grep og hvordan TPS kan og bør integreres i utdanningene. Forfatterne legger vekt på at TPS må introduseres tidlig i utdanningsforløpet i alle studieløp, og at kulturendringer må til.

Under et studiebesøk ved Universitetet i Linköping i Sverige, som organiserer TPS i studentdrevne avdelinger, kom det, i en samtale med en av studentene, frem at han visste at praksisen var tverrprofesjonell, men han hadde ikke noe bevisst forhold til hvorfor det var relevant for hans utdanning. Han signaliserte en uklar oppfatning av hensikten med TPS. Her har utdanningene et stort ansvar. TPS må forberedes grundig for studentene, og man må diskutere hva forberedelsene skal inneholde for at det skal oppleves som meningsfullt. Det bør settes av tid til å undervise om de andre helseprofesjonene, der utarbeidelse og bruk av enkelte felles læringsutbyttebeskrivelser kan tjene som en inngang til undervisningen. Man kan også legge til rette for tverrfaglige diskusjoner. Dette kan bidra til å gjøre studentene nysgjerrige på den andre, og på hva de kommer til å møte i praksis. Kommunikasjonsferdigheter må oppøves, ikke bare i pasientsituasjoner, men også profesjonene imellom. Nelson et al. (2014) presiserer at å lære sammen ikke er det samme som å lære samarbeid. Dette kan være utfordrende for utdanningene, men det bør adresseres.

TPS-prosjekter varierer mellom situasjonsbestemte samarbeid (som Inter Sim og samarbeid rundt sårbehandling) og til prosjekter som spenner over flere uker, for eksempel studentdrevne sykehusavdelinger. I definisjonen på TPS heter det «lærer om, fra og med hverandre» (WHO, 2010, s. 7). Hva legger vi i betydningen «lærer om hverandre»? Samarbeid kan være et stikkord her. 
Det er også viktig å gi studentene redskaper for refleksjon underveis i TPS-prosjektene. Forberedelser knyttet mot det å samarbeide i en gruppe med ulike profesjoner kan være av betydning. Studentene kan introdusere sin egen profesjon for hverandre, hva kan egen profesjon bidra med, hva er ulikt, og hva er felles. Hvordan ser studentene på hverandres profesjon? Det er viktig å tematisere hvordan vi henvender oss til hverandre, hvordan vi viser hverandre gjensidig respekt, og hvordan vi adresserer utfordringer underveis på en ryddig og konstruktiv måte. En læringsarena kan være fokusgruppeintervjuer sammensatt av studenter fra ulike profesjoner for å klargjøre roller og for å snakke om forventninger og kommunikasjon allerede før pasientnære TPS-situasjoner. Studien til Aase fremholder at fokusgruppeintervjuet etter TPS ble den beste arenaen for utveksling av kunnskap og erfaringer (Aase et al., 2014).

I tillegg til arenaer for TPS rundt pasientarbeid, kan TPS også gjennomføres i en mer teoretisk kontekst. Mange studiesteder benytter medisinere i undervisningen av andre helseprofesjoner. Tilsvarende kan gjennomføres også mot medisinutdanningene. Å benytte andre helseprofesjoner i deres undervisning kan bidra til økt forståelse av deres rolle.

En studie fra New Zealand diskuterer når i studieforløpet det er hensiktsmessig å introdusere TPS (Horsburgh, Lamdin \& Williamson, 2001). Enkelte studier argumenterer for at det er mest relevant å ha TPS mot slutten av utdanningen (Horsburgh et al., 2001; Wong, Fahs, Talwalkar, Colson, Desai, Kayingo \& Rosenthal, 2016). Andre introduserer TPS allerede i første studieår. Tradisjonelle oppfatninger og fordommer om for eksempel medisin eller sykepleie kan stå for fall gjennom endrede samarbeidsformer. Mange studier avdekker felles utfordringer samtidig som de etterlyser mer forskning på området. Ikke minst etterlyses forskning på tverrprofesjonell lærings betydning for yrkeslivet etter endt utdanning.

\section{Avslutning}

Jeg har i dette kapittelet diskutert roller, læring og studentsamarbeid i TPS i lys av prosjekter gjennomført mellom medisinstudenter og sykepleierstudenter. Diskusjonen peker på noen utfordringer i de to studentprosjektene, men også gode erfaringer knyttet til de temaene studentene adresserer. TPS bør gi 
et solid grunnlag for videre tverrprofesjonell utvikling og ikke bare begrenses til en gang per utdanningsforløp. Jeg vil også fremheve betydningen av studentenes evne til å beskrive eget fag. Dette bør knyttes opp mot forberedelser til praksisnære TPS-prosjekter og læringssituasjoner.

Det kan by på utfordringer å integrere TPS i studieplaner slik at det kan gjennomføres uten at det kommer i konflikt med arbeidskrav eller fagspesifikke emner i det enkelte studieprogram. Utfordringer kan også være store studiekull og behovet for at undervisningen skal drives på en kostnadseffektiv måte.

Ved UiT Norges arktiske universitet har man siden 2003 gjennomført et ti studiepoengs fellesemne for alle helseprofesjoner. Kommunikasjon er et av temaene som er viet mye plass i dette emnet, da spesielt kommunikasjon med pasienter/brukere. En god kommunikasjon mellom helsearbeidere vil være av stor betydning for kvaliteten på helsetjenesten. Dette bør løftes frem i studiene. Studier av TPS-prosjekter etterlyser ofte forskning på hvilken betydning TPS i utdanningene har for samarbeidet til ferdig utdannet helsepersonell. I dette forskningsfeltet ligger det store muligheter til kunnskap om hvorvidt øt fokus på TPS i utdanningene fører til bedre samarbeid mellom yrkesgruppene etter endt utdanning, og om det øker kvaliteten i pasientbehandlingen.

\section{Referanser}

Andersen, I. A. Baerheim, A. \& Hovland, G. (2017). Lege- og sjukepleiestudentar sine opplevingar av tverrprofesjonell samarbeidslæring i spesialisthelsetenesta: ein kvalitativ studie. Uniped 40(04), s. 361-373.

DOI: https://doi.org/10.18261/issn.1893-8981-2017-04-07

Bandura, A. \& Walters, R. H. (1977). Social learning theory. Englewood Cliffs, N.J: Prentice Hall.

CAIPE. (2017). Interprofessional Education Guidelines. Fareham, United Kingdom: CAIPE.

Cheetham, N. B. (2016). Får innsikt i hverandres fag. Sykepleien, 9(9), s. 48-50.

DOI: https://doi.org/10.4220/Sykepleiens.2016.58637 
Clark, P. G. (2011). Examining the interface between interprofessional practice and education: Lessons learned from Norway for promoting teamwork. Journal of Interprofessional Care, 2011, Vol.25(1), s. 26-32.

DOI: https://doi.org/10.3109/13561820.2010.497751

Delunas, R. L. \& Rouse, R. S. (2014). Nursing and Medical Student Attitudes About Communication and Collaboration Before and After an Interprofessional Education Experience. Nursing Education Perspectives, 35(2), s. 100-105. DOI: https://doi.org/10.5480/11-716.1

Ebert, L., Hoffman, K., Levett-Jones, T. \& Gilligan, C. (2014). "They have no idea of what we do or what we know": Australian graduates' perceptions of working in a health care team. Nurse Education in Practice, 14(5), s. 544-550.

DOI: https://doi.org/10.1016/j.nepr.2014.06.005

Friman, A., Wiegleb Edström, D. \& Edelbring, S. (2017). Attitudes and perceptions from nursing and medical students towards the other profession in relation to wound care. Journal of interprofessional care, 31(5), s. 620-627.

DOI: https://doi.org/10.1080/13561820.2017.1336991

Gudmundsen, A. C., Norbye, B., Abrandt Dahlgren, M. \& Obstfelder, A. (2019). Interprofessional Education: Student's Learning of Joint Patient Care. Professions and Professionalism, 9(1), s. 1-14 DOI: https://doi.org/11250/2580786

Gudmundsen, A. C., Norbye, B., Dahlgren, M. A. \& Obstfelder, A. (2018).

Interprofessional student meetings in municipal health service - Mutual learning towards a community of practice in patient care. 33(1).

DOI: https://doi.org/10.1080/13561820.2018.1515732

Horsburgh, M., Lamdin, R. \& Williamson, E. (2001). Multiprofessional learning: the attitudes of medical, nursing and pharmacy students to shared learning. Medical education, 35(9), s. 876-883.

DOI: https://doi.org/10.1046/j.1365-2923.2001.00959.x

Ingstad, K. (2013). Sosiologi i sykepleie og helsearbeid. Oslo: Gyldendal Akademisk.

Kalvenes, M., Hjelle, K. M. \& Tuven, K. (2016). Tverrfagleg praksis gjev auka innsikt. Sykepleien 2016;104 (3), s. 62-65. https://sykepleien.no/forskning/2016/02/tverrprofesjonelt-samarbeid

Kristensen, D. V., Flo, J. \& Fagerstrøm, L. (2014). Tverrprofesjonell klinisk praksis for helsefagstudenter som en del av den ordinære praksisperioden, En casestudie fra en akutt geriatrisk-, slag- og rehabiliteringsavdeling. Nordisk tidsskrift for helseforskning, 10(1) s. 83-95. DOI: https://doi.org/10.7557/14.3012 
Kvale, S., Brinkmann, S., Anderssen, T. M. \& Rygge, J. (2015). Det kvalitative forskningsintervju (3. utg.). Oslo: Gyldendal Akademisk.

Lave, J., \& Wenger, E. (2003). Situeret laring - og andre tekster. København: Hans Reitzels.

Lidskog, M., Löfmark, A. \& Ahlström, G. (2008). Students' learning experiences from interprofessional collaboration on a training ward in municipal care. Learning in Health and Social Care, 7(3), s. 134-145. DOI: https://doi.org/10.1111/j.1473-6861.2008.00181.x

Lockeman, K. S., Appelbaum, N. P., Dow, A. W., Orr, S., Huff, T. A., Hogan, C. J. \& Queen, B. A. (2017). The effect of an interprofessional simulation-based education program on perceptions and stereotypes of nursing and medical students: A quasi-experimental study. Nurse Education Today, 58, s. 32-37. DOI: https://doi.org/10.1016/j.nedt.2017.07.013

Molander, A. \& Terum, L. I. (2008). Profesjonsstudier. Oslo: Universitetsforlaget. Nasjonale retningslinjer for helse- og sosialfagutdanningene (RHETOS) https:// lovdata.no/dokument/SF/forskrift/2017-09-06-1353 Hentet 09.11.2021

Nelson, S., Tassone, M. \& Hodges, B. D. (2014). Creating the health care team of the future: the Toronto Model for interprofessional education and practice. Toronto: Cornell University Press.

Norbye, B. (2016). Healthcare students as innovative partners in the development of future healthcare services: An action research approach. Nurse Education Today, 46, s. 4-9. DOI: https://doi.org/10.1016/j.nedt.2016.06.021

Park, J., Hawkins, M., Hamlin, E., Hawkins, W. \& Bamdas, J. A. M. (2014). Developing Positive Attitudes Toward Interprofessional Collaboration Among Students in the Health Care Professions. Educational Gerontology, 40(12), s. 894-908. DOI: https://doi.org/10.1080/03601277.2014.908619

Renschler, L., Rhodes, D. \& Cox, C. (2016). Effect of interprofessional clinical education programme length on students' attitudes towards teamwork. Journal of interprofessional care, 30(3), s. 338-346.

DOI: https://doi.org/10.3109/13561820.2016.1144582

Rose, M. A., Smith, K., Veloski, J. J., Lyons, K. J., Umland, E. \& Arenson, C. A. (2009). Attitudes of students in medicine, nursing, occupational therapy, and physical therapy toward interprofessional education. Journal of Allied Health, 38(4), s. 196-200. https://www.ingentaconnect.com/contentone/asahp/ jah/2009/00000038/00000004/art00003;jsessionid $=479 \mathrm{hbav} 4$ brbk4.x-iclive-02 Hentet 09.11.2021 
Säljö, R. \& Moen, S. (2001). Laring i praksis: et sosiokulturelt perspektiv. Oslo: Cappelen Akademisk.

Sylte, A. L. (2018). Profesjonspedagogikk. Oslo: Gyldendal.

Utdanning for velferd - samspill i praksis Meld. St. 13. (2011-2012). Oslo:

Kunnskaps departementet. https://www.regjeringen.no/contentassets/

ac91ff2dedee43e1be825fb097d9aa22/no/pdfs/stm201120120013000dddpdfs. pdf Hentet 09.11.2021

WHO. (2010). A WHO Report: Framework for Action on Interprofessional Education \& Collaborative Practice. https://apps.who.int/iris/bitstream/ handle/10665/70185/?sequence $=1$ Hentet 09.11.2021

Wong, R. L., Fahs, D. B., Talwalkar, J. S., Colson, E. R., Desai, M. M., Kayingo, G. \& Rosenthal, M. S. (2016). A longitudinal study of health professional students attitudes towards interprofessional education at an American university. Journal of interprofessional care, 30(2), s. 191-200.

DOI: https://doi.org/10.3109/13561820.2015.1121215

Aase, I., Hansen, B. S. \& Aase, K. (2014). Norwegian nursing and medical students' perception of interprofessional teamwork: a qualitative study. BMC medical education, 14(1), 170. DOI: https://doi.org/10.1186/1472-6920-14-170

Aase, I., Aase, K. \& Dieckmann, P. (2013). Teaching interprofessional teamwork in medical and nursing education in Norway: A content analysis. Journal of interprofessional care, 27(3), s. 238-245.

DOI: https://doi.org/10.3109/13561820.2012.745489 